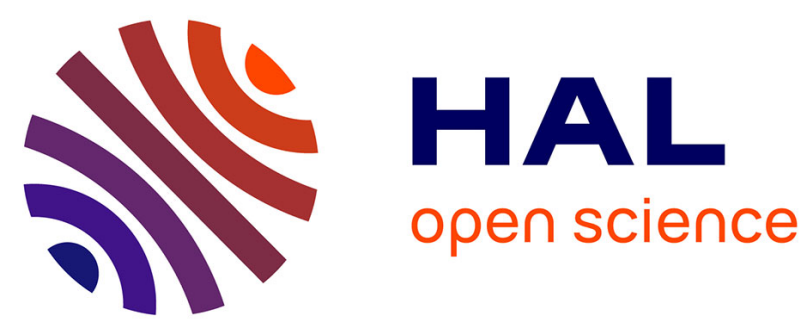

\title{
PROFITABILITY OF INVESTMENTS IN EDUCATION. EVIDENCE FROM SPANISH REGIONS
}

Rosina Moreno, Enrique López-Bazo

\section{> To cite this version:}

Rosina Moreno, Enrique López-Bazo. PROFITABILITY OF INVESTMENTS IN EDUCATION. EVIDENCE FROM SPANISH REGIONS. Regional Studies, 2011, pp.1. 10.1080/00343404.2010.543893 . hal-00677964

\section{HAL Id: hal-00677964 https://hal.science/hal-00677964}

Submitted on 11 Mar 2012

HAL is a multi-disciplinary open access archive for the deposit and dissemination of scientific research documents, whether they are published or not. The documents may come from teaching and research institutions in France or abroad, or from public or private research centers.
L'archive ouverte pluridisciplinaire HAL, est destinée au dépôt et à la diffusion de documents scientifiques de niveau recherche, publiés ou non, émanant des établissements d'enseignement et de recherche français ou étrangers, des laboratoires publics ou privés. 


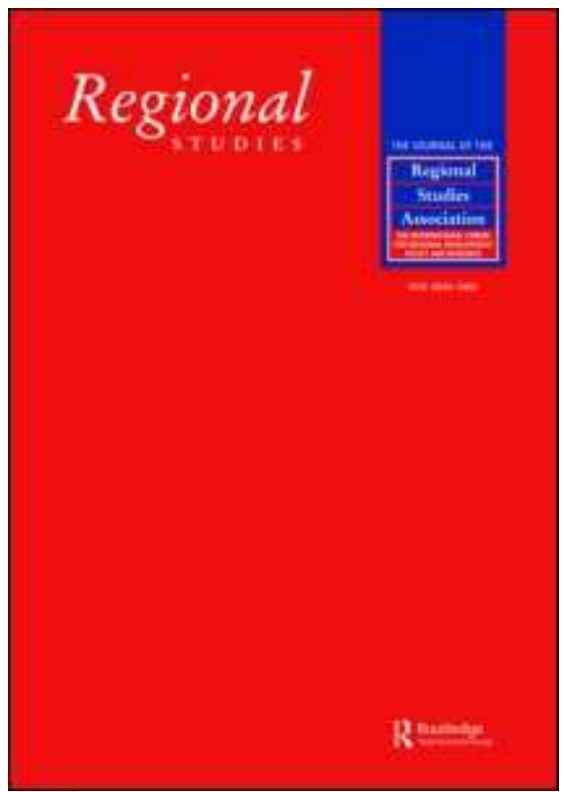

\section{PROFITABILITY OF INVESTMENTS IN EDUCATION. EVIDENCE FROM SPANISH REGIONS}

\begin{tabular}{|c|l|}
\hline Journal: & Regional Studies \\
\hline Manuscript ID: & CRES-2009-0336.R1 \\
\hline Manuscript Type: & Main Section \\
\hline JEL codes: & $\begin{array}{l}\text { O18 - Regional, Urban, and Rural Analyses < O1 - Economic } \\
\text { Development < O - Economic Development, Technological Change, } \\
\text { and Growth, O47 - Measurement of Economic Growth|Aggregate } \\
\text { O - Economic Development, Technological Change, and Growth, } \\
\text { R11 - Regional Economic Activity: Growth, Development, and } \\
\text { Changes < R1 - General Regional Economics < R - Urban, Rural, } \\
\text { and Regional Economics }\end{array}$ \\
\hline \hline Keywords: & \begin{tabular}{l} 
economic development, education, productivity, rate of return \\
\hline
\end{tabular} \\
\hline
\end{tabular}

\section{SCHOLARONE \\ Manuscripts}




\title{
PROFITABILITY OF INVESTMENTS IN EDUCATION.
} EVIDENCE FROM SPANISH REGIONS

\author{
Enrique López-Bazo ${ }^{\mathrm{a}}$ \\ Rosina Moreno ${ }^{\mathrm{b}}$ \\ University of Barcelona \\ a European Commission, Joint Research Centre (JRC), Institute for Prospective Technological \\ Studies (IPTS), C/ Inca Garcilaso 3, 41092 Seville, Spain \\ $\&$ \\ AQR Research Group_-IREA, Dept. of Econometrics, Statistics and Spanish Economy, \\ University of Barcelona, Avda Diagonal 690, 08034 Barcelona, Spain \\ Phone: +34 934037041, FAX: +34 934021821, E-mail: elopez@ub.edu \\ b AQR Research Group-IREA, Dept. of Econometrics, Statistics and Spanish Economy, \\ University of Barcelona, Avda Diagonal 690, 08034 Barcelona, Spain \\ Phone: +34 934021823, FAX: +34 934021821, E-mail: rmoreno@ub.edu \\ (Received November 2009: in revised form November 2010)

\footnotetext{
a. The author is solely responsible for the content of the paper. The views expressed are purely those of the author and may not in any circumstances be regarded as stating an official position of the European Commission.
} 


\begin{abstract}
:
The objective of this paper is to furnish new evidence concerning the aggregate profitability of the accumulation of educational human capital. In addition to the traditional measure of the return to human capital, combining the information on its shadow price with the social cost of providing education allows us to confirm the profitability of investments in education as a tool for promoting economic growth. The possibility of obtaining estimations of these effects for each Spanish region enables us to empirically evaluate the amount of heterogeneity across regions in the effects of human capital.
\end{abstract}

Keywords: economic development, education, productivity, rate of return JEL: O180, O470, R110 


\section{INTRODUCTION}

The effect that education can have on a society, as a mechanism that generates human capital, has meant that today the principal motivation underpinning human capital theory has been extended from simply accounting for wage differentials between individuals to that of explaining economic growth (Willis, 1986). Predictions of a range of theoretical models of economic growth (e.g. Lucas, 1988) has given rise to many empirical exercises linking aggregate productivity and growth with the endowment of human capital (e.g. Mankiw, Romer \& Weil, 1992; Benhabib and Spiegel, 1994; Bils and Klenow, 2000; Krueger and Lindahl, 2001). Despite recent findings that lend support to a positive effect of human capital based on the use of what is more refined human capital data (de la Fuente and Doménech, 2006), and to the link between economic performance and non-traditional measures of human capital such as the matching of educational supply and local labor market needs (RodríguezPose and Vilalta-Bufí, 2005), the debate on the real contribution of human capital investments in promoting economic growth is by no means settled, and the evidence from an aggregate perspective on the effects of human capital on growth remains unclear (Temple 2001).

Many studies have not only identified human capital as being a major factor in determining a significant part of the levels and growth rates of productivity and per capita income (Mankiw et al., 1992; Barro, 2001), but they have also identified human capital as being a key element in strengthening the effect of other factors considered essential for economic growth, such as investment in technology (Romer, 1990; Aghion and Howitt, 1998) and trade openness (Miller et al, 2000; López-Bazo, Requena \& Serrano, 2006). As a result, recent contributions have stressed the role of human capital in explaining growth differences across countries (Krueger and Lindahl, 2001; Bassanini and Scarpetta, 2002; Engelbrecht, 2003) and across regions within countries (Cheshire and Magrini, 2000; Fingleton, 2004; Di Liberto, 2008). It 
is of little surprise then that financing the accumulation of human capital in the least developed economies through the educational system has been suggested as one of the main measures of development policy.

In this context, the first aim of this paper is to check whether human capital is a profitable investment once the cost of providing it is taken into account. With this purpose, we show how the use of the dual framework (Berndt, 1991), through the specification of a cost system, can provide with this additional evidence concerning the contribution of human capital, acquired in the formal education system, to regional economic growth. ${ }^{1}$ In this sense, the first step we give is to compute the return to human capital obtained with the estimates of a cost function aggregated with human capital, and compare it with the returns previously obtained in the literature estimating production functions. In a second step and thanks to the estimation of a cost system, we obtain the shadow price of human capital, defined as the price that the firms in the region would have been willing to pay for an additional year of education of all the employees in the economy. Combining the information on the shadow price with the social cost of providing education in each regional economy allows us to confirm the profitability of human capital investments as a tool for promoting economic growth. This second step is the major value added of this paper, since such measure of profitability can not be obtained through a production framework. Morrison and Siegel (1997) is one of the only studies to analyze some of the effects of human capital endowment on production activity by adopting the duality approach, in a more general context of the study of the effects of the accumulation of knowledge. ${ }^{2}$ Yet, such study does not explore the possibility of obtaining an estimate of the return to human capital, or, for that matter, of any other measures of interest in the study of the effect of this capital such as the shadow price. 
As far as we know this analysis has not been previously addressed in the literature, and it is possible to deal with it in our case due to the use of the dual approach and the availability of data on the public and private costs of a year of education in the formal educational system in each of the Spanish regions. ${ }^{3}$ In addition to that, the evidenced obtained from Spain might be paradigmatic when it comes to evaluating the contribution of this type of factor to economic development and to the evolution of regional imbalances. The level of education experienced a spectacular increase in all the Spanish regions in the last decades, though significant interregional differences in the level of education still remain. Interestingly, following the accession to the European Union, the country as a whole and, to a greater or lesser extent, all the regions opened to competition, and underwent a process of modernization of the productive and institutional structures. These processes have been shown to enhance the positive effect of human capital investments on productivity as they allow high-skilled individuals to obtain the appropriate return from the investments they made in education (Miller and Upadhyay, 2000; López-Bazo et al, 2006). .

We thus consider that the setting is adequate for assessing whether human capital can really promote economic growth, especially when this occurs in combination with other elements that might allow both individuals and regions to use this capital in productive activities for which they receive their corresponding return. Actually, we would expect the effect of human capital to be homogenous in all regions in the case that they were also homogenous in other aspects, such as in their productive structure, in their propensity to generate and adopt innovations and in their engagement in trade. Were this not the case, it is possible that the return to human capital would differ between regions, which means that an appraisal of its value as a tool for use in development policy would be particularly useful if information about the distribution of this effect across regions was available. Our empirical approach allows 
estimating the above-mentioned effect for each of the regions under analysis and, thus, assessing the particular contribution of human capital to economic growth in each of them. To provide evidence of the heterogeneous profitability of human capital in the Spanish regions constitutes the second main objective of this paper.

The rest of this paper is organized as follows. In the second section we present the model based on the duality theory that includes the human capital stock as a factor that influences the technology of production in an economy, and describe the empirical specification from which the effects of educational human capital will be estimated. The third section describes the dataset and the major variables in the empirical analysis, paying special attention to the accumulation of human capital in the Spanish regions over the last decades, while the results are reported in the fourth. The fifth section concludes.

\section{EMPIRICAL FRAMEWORK}

The aggregate variable cost function corresponding to an aggregate production function expanded with human capital can be expressed as follows:

$$
\mathrm{VC}=\mathrm{VC}\left(\mathrm{P}_{\mathrm{L}}, \mathrm{P}_{\mathrm{M}}, \mathrm{Y}, \mathrm{K}, \mathrm{H}\right)
$$

where we consider two variable inputs, labor (L) and intermediates $(M)$ which appear in the cost function through their prices, $\mathrm{P}_{\mathrm{L}}$ and $\mathrm{P}_{\mathrm{M}}$ respectively; a quasi-fixed input, physical capital, $\mathrm{K} ; \mathrm{Y}$ is output and $\mathrm{H}$ is human capital. ${ }^{4}$ In other words, economies of scale in a cost function are now outlined to include this new argument, so that variations in the human capital stock available in the economy can lead to shifts in cost curves. The corresponding short-run cost function is the sum of the variable cost and the cost of the services provided by the existing capital:

$$
\mathrm{SC}=\mathrm{VC}(\cdot)+\mathrm{P}_{\mathrm{K}} \cdot \mathrm{K}
$$


where $\mathrm{P}_{\mathrm{K}}$ is the physical capital cost of use.

The functional form chosen for the empirical work is based on a translog variable cost function, a general second degree polynomial in logs, with the following form:

$$
\begin{aligned}
& \ln \left(\mathrm{VC} / \mathrm{P}_{\mathrm{M}}\right)=\beta_{0}+\beta_{\mathrm{L}} \ln \frac{\mathrm{P}_{\mathrm{L}}}{\mathrm{P}_{\mathrm{M}}}+\beta_{\mathrm{Y}} \ln \mathrm{Y}+\beta_{\mathrm{K}} \ln \mathrm{K}+\beta_{\mathrm{H}} \ln \mathrm{H}+\beta_{\mathrm{T}} \mathrm{t}+ \\
& 0.5\left[\beta_{\mathrm{LL}} \ln ^{2} \frac{\mathrm{P}_{\mathrm{L}}}{\mathrm{P}_{\mathrm{M}}}+\beta_{\mathrm{YY}} \ln ^{2} \mathrm{Y}+\beta_{\mathrm{KK}} \ln ^{2} \mathrm{~K}+\beta_{\mathrm{HH}} \ln ^{2} \mathrm{H}+\beta_{\mathrm{TT}} \mathrm{t}^{2}\right] \\
& +\beta_{\mathrm{LY}} \ln \frac{\mathrm{P}_{\mathrm{L}}}{\mathrm{P}_{\mathrm{M}}} \ln \mathrm{Y}+\beta_{\mathrm{LK}} \ln \frac{\mathrm{P}_{\mathrm{L}}}{\mathrm{P}_{\mathrm{M}}} \ln \mathrm{K}+\beta_{\mathrm{LH}} \ln \frac{\mathrm{P}_{\mathrm{L}}}{\mathrm{P}_{\mathrm{M}}} \ln \mathrm{H}+\beta_{\mathrm{LT}} \ln \frac{\mathrm{P}_{\mathrm{L}}}{\mathrm{P}_{\mathrm{M}}} \mathrm{t} \\
& +\beta_{\mathrm{YK}} \ln \mathrm{Y} \ln \mathrm{K}+\beta_{\mathrm{YH}} \ln \mathrm{Y} \ln \mathrm{H}+\beta_{\mathrm{YT}} \ln \mathrm{Yt}+\beta_{\mathrm{KH}} \ln \mathrm{K} \ln \mathrm{H}+\beta_{\mathrm{KT}} \ln \mathrm{K} \mathrm{t}+\beta_{\mathrm{HT}} \ln \mathrm{Ht}
\end{aligned}
$$

where $\mathrm{t}$ is a time trend which summarizes technological change. For ease of notation, variables in equation (3) onwards do not carry subscripts referring to the observations.

This functional form permits the consideration of a wide range of substitution possibilities and can be accommodated within any production technology without the need to impose a priori restrictions on returns to scale. Intermediate prices are included as a relative factor to ensure that the function is homogeneous of degree one in factor prices and symmetry conditions are imposed (Berndt, 1991). Besides, no kind of a priori returns to scale is imposed.

The share equations for variable inputs on variable costs are obtained through the differentiation of equation (3) with respect to variable input prices, $\partial \mathrm{VC}(\cdot) / \partial \mathrm{P}_{\mathrm{i}}$, with $\mathrm{i}=\mathrm{L}, \mathrm{M}$ according to the Shephard's lemma. For the two variable factors we consider here, only one equation is independent, given that factor shares sum to one. Thus, we have: 


$$
\begin{aligned}
& \mathrm{S}_{\mathrm{L}} \equiv \frac{\mathrm{P}_{\mathrm{L}} \cdot \mathrm{L}}{\mathrm{VC}}=\frac{\partial \ln \mathrm{VC}}{\partial \ln \mathrm{P}_{\mathrm{L}}}=\beta_{\mathrm{L}}+\beta_{\mathrm{LL}} \ln \frac{\mathrm{P}_{\mathrm{L}}}{\mathrm{P}_{\mathrm{M}}}+\beta_{\mathrm{LY}} \ln \mathrm{Y}+\beta_{\mathrm{LK}} \ln \mathrm{K}+\beta_{\mathrm{LH}} \ln \mathrm{H}+\beta_{\mathrm{LT}} \mathrm{t} \\
& \mathrm{S}_{\mathrm{M}} \equiv 1-\mathrm{S}_{\mathrm{L}}
\end{aligned}
$$

Finally, differentiating logarithmically the function of $\mathrm{VC}(\cdot)$ with respect to $\mathrm{Y}$ and introducing the condition of equality between the price of the output and the marginal cost, we obtain the output market equilibrium condition:

$$
\mathrm{S}_{\mathrm{Y}} \equiv \frac{\mathrm{P}_{\mathrm{Y}} \cdot \mathrm{Y}}{\mathrm{VC}}=\frac{\partial \ln \mathrm{VC}}{\partial \ln \mathrm{Y}}=\beta_{\mathrm{Y}}+\beta_{\mathrm{YY}} \ln \mathrm{Y}+\beta_{\mathrm{LY}} \ln \frac{\mathrm{P}_{\mathrm{L}}}{\mathrm{P}_{\mathrm{M}}}+\beta_{\mathrm{YK}} \ln \mathrm{K}+\beta_{\mathrm{YH}} \ln \mathrm{H}+\beta_{\mathrm{YT}} \mathrm{t}
$$

The set of expressions (3)-(5) would comprise the framework of the partial static equilibrium, that is used in the rest of the paper to obtain the measures of the effects of human capital.

\section{DATABASE}

The spatial units considered here correspond to the 17 Spanish NUTS II regions ${ }^{5}$ and the period analyzed runs from 1980 to 1995 . Thus, as stated in the introductory section we shall consider the influence of human capital in the private productive sector of the Spanish regions during a period in which there was a marked accumulation of human capital in all the regions, in conjunction with the modernization of the Spanish economy and its opening up to the exterior following integration into the European Union.

The measure used for human capital in this study combines the average number of years in each level of education with the percentage of the population in each of these levels, thereby producing an attractive synthetic indicator of educational human capital, like that of the average number of years of education of an economy. This type of indicator has been constructed for various samples of economies by, among others, Kyriacou (1991), Barro and Lee $(1993,1996,2001)$, and has been used to analyze the contribution of this factor to growth 
in, for example, Benhabib and Spiegel (1994), Temple (1999), DiLiberto (2008) and Pereira and Aubyn (2009). ${ }^{6}$ The information required for constructing the indicator was drawn from Mas, Pérez, Uriel, Serrano \& Soler (2002).

We have information for five levels of education: no schooling, primary education, secondary education, first level of higher education, and second level of higher education. Given that this information is tabulated for, among other groups, the workers employed in each period, it is possible to obtain the percentage of workers for each of these levels of education, for the period 1964 to 2001. We have followed Serrano (1996) by designating 0 years to workers with no schooling, 3.5 years to the group with primary education studies, 11 years to those having completed secondary education, 16 years to those workers with a first level of higher education and 17 years to those with a second level of higher education.

Figure 1 illustrates the evolution in the education of the working population engaged in the private productive sector of the Spanish economy as a whole. It clearly reveals the important growth in the level of education of the working population described above. The group of workers with no schooling virtually disappears and primary education - the preponderant level for much of this period for which data are available - is supplanted by secondary education. Although smaller in number, the increase in the percentage of workers with university studies is notable as well.

[Insert Figure 1 around here]

Correspondingly, the average years of schooling of workers in the private productive sector of the Spanish economy increased notably throughout the period (Figure 2). In particular, the 
increase during the period in which this study is focused was even more intense than in earlier periods. Thus, in a decade and a half there was an increase of more than three years, reaching 8.34 years in 1995. Although the period following this year is not included in the analysis undertaken here, it should be pointed out that this trend shows no sign of weakening.

\section{[Insert Figure 2 around here]}

The results obtained for Spain as a whole are reproduced in the case of all the regions, although marked differences persist in the regional endowment of human capital at the end of the period. Specifically, Figure 3 shows the average years of education of those employed in the private sector in 1980 and in 1995, i.e. the first and last years of the period analyzed in our subsequent study. It can be seen how, despite the convergence in the levels of human capital over the period, marked differences persist across regions. Thus, compared to 9.6 years in Madrid in 1995, Galicia and Extremadura do not reach 7 years.

\section{[Insert Figure 3 around here]}

Therefore, the increase in the education stock in all the regions and the existence of marked variability among them should provide us with substantial information for comparing the effect that educational attainment has on aggregate productivity and economic growth which, as discussed above, will enable us to draw conclusions as to the aggregate return to investment in human capital.

The remaining statistical information has been taken from the BD.MORES database prepared by the Spanish Ministry of Economy and Finance (Dabán, Díaz, Escribá \& Murgui, 1998). 


\section{RESULTS}

\subsection{Estimate of the coefficients of the cost system}

For purposes of empirical implementation the models discussed in section 2 have to be embedded within a stochastic framework. In order to do this we consider errors in variable costs -eq. 3- and variable factor demands - eq. 4- as being due to errors in optimization in the short-run, while that for the equilibrium in the output market - eq. 5- represents unanticipated information that becomes available once the decision on the amount to produce has been taken. To allow for separate elasticities across groups of regions we have included two dummy variables interacting with the linear terms of the variable factor prices, the stock of physical capital and output. Correspondingly, those dummies have been included as well in the factor share equations and in those for the equilibrium condition of output. The first of these dummies (D1) controls for the size of the regional economy, in terms of the share of its output over the one of the country. The second (D2) is included to account for the situation in some regions in which the ratio of physical to human capital was fairly low. ${ }^{7}$

The unknown coefficients in the model were estimated using the iterative Zellner technique for seemingly unrelated regression equations, which converge to the maximum likelihood estimator for models of this type. In this regard, it should be mentioned that in addition to the 
set of equations (3) to (5), the estimated cost system included an additional equation for the short-run demand of physical capital. This is so to account for the likely correlation between the shocks that affect this quasi-fix factor and the other variables in the system. However, according to the partial static equilibrium framework, no constraints between the coefficients of that additional equation and the set of coefficients in the variable cost system in (3) to (5) were imposed in the estimation. ${ }^{8}$

The results of the estimation are shown in Table 1. The restrictions between the parameters of equation 3 and those of equations 4 and 5 are imposed (column i, where we only give the estimates of equation 3 to avoid repetition), whereas as indicated above the equation for the short-run demand of physical capital is estimated in the model without imposing restrictions between its parameters and the others from the cost system (column ii). In addition, we show the results obtained from the likelihood-ratio test of the null hypothesis of which the matrix of covariances of the disturbance of the system of equations is diagonal - in other words, the contrast of the fit of the cost system as a model of apparently unrelated equations. The value obtained for the test statistic (108.8) lies clearly within the rejection zone of the null hypothesis, so that the Zellner estimation for the SURE-type estimation is adequate.

[Insert Table 1 around here]

It should be pointed out that it is unreasonable to undertake any kind of interpretation or structural analysis directly from the estimated parameters, given that we are using the translog approximation of the unknown functional form underlying the cost system. Similarly, it is worth stressing that convergence in the estimation was reached with a relatively small number of iterations and, more importantly from an economic point of view, that the coefficients of 


\subsection{Aggregate returns to human capital}

There are various measures easily derived from the estimation of the cost system defined in section 2 that allow us to quantify and evaluate the contribution of investments in human capital to economic growth. The first one is the change in production costs due to a marginal addition to the stock of human capital, the cost elasticity of human capital, defined as:

$$
\varepsilon_{\mathrm{SC}, \mathrm{H}} \equiv \frac{\partial \ln \mathrm{SC}}{\partial \ln \mathrm{H}}=\frac{\partial \mathrm{SC}}{\partial \mathrm{H}} \frac{\mathrm{H}}{\mathrm{SC}}=\frac{\partial \mathrm{VC}}{\partial \mathrm{H}} \frac{\mathrm{H}}{\mathrm{SC}}
$$

The elasticity in (6) is negative when additions to the stock of educational human capital save costs of production in a given economy. That is, when they contribute to improve productivity. In connection with the cost elasticity is the traditional elasticity of output to human capital usually obtained in growth studies analyzing the effects of human capital. ${ }^{9}$ This measure can be recovered from the dual approach thanks to the envelope theorem (see Chambers, 1988):

$$
\varepsilon_{\mathrm{Y}, \mathrm{H}}=\frac{\partial \ln \mathrm{Y}}{\partial \ln \mathrm{H}}=\frac{-\frac{\partial \mathrm{VC}}{\partial \mathrm{H}}}{\frac{\partial \mathrm{SC}}{\partial \mathrm{Y}}} \frac{\mathrm{H}}{\mathrm{Y}}
$$

This relationship provides the connection between the primal (via the production function) and the dual (via the cost function) measurement of the productivity impact of capital stocks. However, in the case of educational human capital it is more intuitive to analyze the impact of an additional year of education on output. We can define the return to human capital as the increase in output given an increase of one year in the average level of education of the labor force. This semi-elasticity of output with respect to human capital is given by: 


$$
\mathrm{R}_{\mathrm{H}} \equiv \frac{\partial \ln \mathrm{Y}}{\partial \mathrm{H}}=\varepsilon_{\mathrm{Y}, \mathrm{H}} \frac{1}{\mathrm{H}}
$$

The cost elasticity in (6) and the return to human capital in (8) can be estimated for each region and year by using the parameters estimated in the cost system and the corresponding values for the variables involved. Table 2 summarizes the results, providing the average for each region throughout the period considered and the global average for a representative Spanish region. ${ }^{10}$ It can be seen in the first column that the improvements in the endowment of human capital gave rise to a saving in total production costs $\left(\varepsilon_{\mathrm{SC}, \mathrm{H}}<0\right)$, which is true in all the Spanish regions. This confirms that the improvement in educational attainment of the working population contributed positively to the returns to scale of the private productive sector. Accordingly, the estimation of the returns to human capital is positive and of a sizeable magnitude in all the regions under analysis, with an average return slightly greater than $9 \%$. In other words, for the mean of the period under consideration and in a typical Spanish region, an increase in one year in the average level of education of the labor force gave rise to an increase of $9 \%$ in output. At this point, it should be born in mind that the estimation of the return to human capital in a cost framework is parallel to the one obtained through using a production function aggregated with the stock of human capital. In this sense, we observe that the magnitude of our estimate for the aggregate return to human capital is of the same order of magnitude as that reported in Bassanini and Scarpetta (2002) for a sample of OECD countries from a growth equation setting. It is also quite similar to the return estimated for the Spanish economy by Serrano (1996) using the production framework, and by Arrazola and de Hevia (2008) using individual data on wages and school attainment.

The positive and non-negligible return for human capital obtained in this paper would therefore justify subsidies being made to estimulate the education of individuals, as an effective tool of development policy given that the resources that are diverted for this purpose 
would be effectively spent, even in comparison with the return obtained from alternative investments. ${ }^{11}$ Yet this global result hides an important regional heterogeneity. Indeed, the mean return to human capital over the period under analysis is very high in the cases of the regions of Aragon, Castilla-Leon, Castilla-La Mancha, Extremadura and Cantabria. By contrast, in Andalucia, Galicia, Catalunya, Valencia, Madrid, Murcia, Navarra and La Rioja the return on human capital was considerably lower. Note, for example, that the return in the region in which investments in human capital were most productive (Extremadura) more than double the region with the lowest return (La Rioja).

\section{[Insert Table 2 around here]}

In short, the investments in education in all the regions of Spain presented far from negligible aggregate impact, given that they contributed significantly to reducing production costs, that is, to increasing the returns of the private productive sector. But the magnitude of this effect was far from homogenous throughout all the regions. This suggests that the return could be related to the level of development attained by each regional economy as well as the existing endowment of educational human capital. In order to analyze these questions, Figures 4 and 5 show the relationship between the estimation of the return on human capital in each region and year, and its productivity and stock of human capital respectively. A trend is noted for the regions with the lowest levels of productivity to benefit most from the accumulation of this factor (Figure 4). ${ }^{12}$ This result supports the idea that, in general terms, investments in human capital might be an effective tool in enhancing productivity in the less developed regions, and that the social or aggregate return to investments in human capital in those regions might even be larger than in the most productive ones. As expected, the estimated return is negatively related to the existing relative stock of human capital. This is derived from Figure 5 in which 
the estimated return for each region and year is related to the corresponding ratio of human to physical capital. The negative relationship confirms that the return was higher in those regions in which there was a shortage of human capital in relation to the stock of physical capital, and suggests that investments in educational human capital should be supported up to the level in which the ratio of human to physical capital is in its equilibrium. That way, the process of regional convergence will be reinforced as the endowment of a factor that has been shown to have a positive influence on growth will be increased in regions with levels of development below the average.

[Insert Figures 4 and 5 around here]

\subsection{Time profile of the returns to human capital}

From the above results it can be deduced that, for the whole period under review, investments in human capital were on average profitable in all the Spanish regions, though their effect might have been stronger in those with low initial endowments of such type of capital and low levels of productivity. This evidence points to the presence of decreasing returns to the accumulation of educational human capital. Actually, under the assumption of diminishing returns for the accumulation of this capital, the continuous increase in its stock throughout the period and in all the regions, as described in Section 3 (Figures 2 and 3), could have brought about a decreasing trend in returns, which could even have led to the exhaustion of this resource as a factor that strengthens growth in the Spanish regional economies at the end of this period. In order to verify this, we have calculated the return for each region in each of the years under consideration and that corresponding to the average of all the Spanish regions. For reasons of space, Table 2 only provides information about the latter. ${ }^{13}$ 
As expected under the assumption of decreasing returns, the most notable feature in the results in the third and fourth columns of Table 2 is the large fall in the returns to human capital. Thus, at the end of the period these returns represented slightly more than $50 \%$ of those observed in 1980. However, the return of an extra year of education at the end of the period in a representative Spanish region maintained its importance (almost 7\%). But interestingly, at the end of the period, the return in some of the regions is rather low $(4.5 \%$ in La Rioja, around 6\% in Catalunya and Madrid) while in some others it remains large enough (10.25\% and $8.4 \%$ in Extremadura and Castilla La Mancha respectively) to strongly support additional investments. Therefore, the lower return of an extra year of education in some of the most economically developed regions in Spain (such as Catalunya and Madrid), compared to those less developed, can be a signal of the existence of diminishing returns for the accumulation of this capital. Given the higher levels of the stock of human capital in those advanced regions, an increase of one extra year of education in their population has lower, although still important, benefits.

Hence, it could be said that while educational human capital in the Spanish regions has played a significant role during the period analyzed, this significance has decreased over time in line with the continuous increase in its stock, and its importance is unlikely to persist with the same strength into the future. Thus, investments in human capital seemed to be a highly effective means of increasing productivity and, hence, promoting economic growth even in the mid-nineties, when the Spanish economy already achieved a substantial degree of economic development. And considering the trend in returns and the current existing stocks, we predict that there is still room for significant returns to human capital investments, particularly in those regions with the smallest endowments. 


\subsection{The shadow price and the cost of provision of human capital}

Results described so far point to positive aggregate returns to investments in human capital. However, to confirm the effectiveness of human capital as a tool for promoting economic growth it would be interesting to relate its effect on productivity, i.e. in saving production costs, with the social cost of provision of additional years of education of the labor force. As far as we know this analysis has not been previously addressed in the literature from an aggregate point of view, and it is possible to deal with it in our case due to the use of the dual approach and the availability of data on the public and private costs of a year of education in the formal educational system in each of the Spanish regions. This analysis therefore comes to complement the measure of the return to human capital, which is the traditional measure obtained in the literature, and can be considered as the main value added of this paper.

In brief, we will state that investments in educational human capital will be socially profitable in a given region when its shadow price, that is the cost saving it causes to the productive sector of that region, exceeds the cost of provision of a year of education for the labor force in the region. We will firstly describe the way in which we compute the above mentioned measures, and then we will discuss the major results for our sample of regions.

If firms in the economy obtain cost reductions due to its aggregate stock of human capital, it can be considered that they will be willing to pay for it up to an amount equal to the savings in cost that this endowment implies. Hence, it is possible to obtain a measure of the implicit willingness of all firms in the economy to pay for educational human capital - that is, the shadow price of human capital:

$$
\mathrm{Z}_{\mathrm{H}} \equiv-\frac{\partial \mathrm{VC}}{\partial \mathrm{H}}=\varepsilon_{\mathrm{VC}, \mathrm{H}}\left(-\frac{\mathrm{VC}}{\mathrm{H}}\right)
$$


where $\varepsilon_{\mathrm{VC}, \mathrm{H}}$ denotes the elasticity of variable costs with respect to human capital $\left(\varepsilon_{\mathrm{VC}, \mathrm{H}} \equiv \frac{\partial \ln \mathrm{VC}}{\partial \ln \mathrm{H}}=\frac{\partial \mathrm{VC}}{\partial \mathrm{H}} \frac{\mathrm{H}}{\mathrm{VC}}\right)$. The shadow price is defined as the reduction in variable costs due to an increase in the stock of human capital. As long as this value is positive, human capital will maintain, to a greater or lesser extent, a net substitutability relationship with variable factors, so that investments in this type of capital will imply improvements in efficiency, the latter understood as net savings as a result of decreases in variable input utilization and thus in variable costs. For the sake of convenience we define the shadow price by worker as $\mathrm{Z}_{\mathrm{H}} / \mathrm{L}$, where $\mathrm{L}$ is the number of workers.

To compare the shadow price of human capital investments with their cost we define a qTobin type of measure as $\mathrm{q}_{\mathrm{H}} \equiv \mathrm{Z}_{\mathrm{H}} / \mathrm{P}_{\mathrm{H}}$, where $\mathrm{P}_{\mathrm{H}}$ is the cost of an additional year of education for the workers in the region. Given that we are using the average years of schooling of the labor force as the measure of human capital, we are actually considering that workers accumulated it throughout the formal system of education. The cost of one year in the educational system financed by the government and the households is the measure used to proxy for $\mathrm{P}_{\mathrm{H}}$. Data for the cost of education comes from the report of Uriel, Moltó, Pérez, Aldás \& Cucarella (1997). It includes the cost per student in the public educational system in the NUTS II Spanish regions for the period 1980 to 1991 . It is obtained by adding to the amount financed by different governmental agencies the expenditure made by households in connection with the education (fees, books, transportation, and so on). The cost in the private educational centers is available as well from the same source, but in this case we have decided not to use this information as it was obtained by an indirect estimation, and its quality is much lower than in the case of the public system, as stressed by the authors of the above-mentioned report. Anyway, the cost of the public system is higher for all regions and years, basically due to higher labor costs in the public versus the private centres. 
[Insert Table 3 around here]

The first column in Table 3 shows the estimates for the shadow price per worker, whereas the cost of one year of education in each region relative to the Spanish average cost is given in the second column, and finally the results for the $\mathrm{q}_{\mathrm{H}}$ are in the third column. It should be noted that, to save space, these figures refer to the average over the period 1980 to 1991 in each of the regions. We find that on average over the period under analysis the firms on a representative Spanish region would have been willing to pay more than $3,000 €$ for an additional year of education of its labor force. This figure represents the savings in variable costs for an additional year of education. However, and as occurred with the return, we should highlight the significant regional variability in the shadow price of human capital (its standard deviation being greater than 570€). Thus, while Aragon, Cantabria and Extremadura exceeded $4,000 €$, Galicia did not reach $2,100 €$.

However, figures in the second column of Table 3 show how the cost of education in the Spanish regions is far from homogeneous as well. For instance, the lowest cost is observed in the lagged regions of Andalucia and Castilla La Mancha with an $87 \%$ of the average cost in Spain, while the cost in some other regions is more than $10 \%$ over the national average. This makes it necessary to relate the shadow price of human capital in each region to the cost for its provision. In accordance with the results in the previous sections, the value for the $\mathrm{q}_{\mathrm{H}^{-}}$ Tobin measure suggests that investments in educational human capital were very profitable in all the regions. On average, the shadow price more than triplicates the cost of the investment, which suggests that, from a social point of view, human capital was in a shortage over the period under analysis. Actually, regional estimates indicate that this was so in all the regions, 
although heterogeneity in both the shadow price and the cost of education causes important regional variation in the $\mathrm{q}_{\mathrm{H}}$ measure. The largest profitability of investments was reached in the lagged regions of Extremadura and Castilla La Mancha, which combined a high shadow price and a relatively low cost. Interestingly, profitability was below the average in some other less-advanced regions, such as Galicia, Andalucía and Canarias.

Summing up, investments in human capital, made through the formal system of education, not only contributed to enhance productivity growth in Spain but were also socially profitable, in the sense that the social return they provided were clearly superior to their cost. But this general result should not hide another important feature, that is the existence of noticeable heterogeneity across regions in the aggregate return and social profitability of human capital. Such heterogeneity should be considered when supporting and financing human capital as a tool for regional development policy.

\section{CONCLUSIONS}

This paper provides a new insight in the analysis of the impact of human capital on regional economic growth through the use of the duality framework to give evidence concerning the aggregate profitability of the accumulation of human capital. We have described an analytical strategy based on the framework supplied by the duality theory that in addition to the return to human capital also allows us to compute the shadow price of investments in this type of capital. Combining the information on the shadow price with the social cost of providing education in each region allows us to assess the profitability of investments in human capital as a tool for promoting economic growth. From a purely economic perspective, the identification of a positive effect would justify the use of public resources for financing 
human capital. Similarly, our results should enable us to assess the use of education as a tool in regional development policy.

We have shown that the return to human capital in Spain was positive throughout the period studied. And this aggregate return is obtained to be superior to the cost of the investments in human capital, made through the formal system of education. This finding would justify the subsidizing of human capital through financing the education of individuals, given that the resources devoted to this purpose would prove profitable. We can affirm, therefore, that it is socially justifiable to dedicate resources to the financing of education given that it results in increases in productivity and, consequently, in greater economic growth.

However, our results confirm that the magnitude of the effect of human capital is far from homogenous across regional economies, even in the case of regions within a country. This result agrees with the recent evidence in Di Liberto (2008) which only obtains a significant positive effect of human capital in the lagging regions of the Italian South. Relating this effect to the level of development attained by each regional economy as well as the existing endowment of human capital, a trend is observed for the regions with the lowest levels of productivity to benefit most from the accumulation of this factor. Similarly, the negative relationship of the return with the existing stock of human capital suggests that no conflict was caused when using the stimulus for investment in human capital in the less developed regions as a development policy measure, given that the objectives of efficiency and equity are simultaneously met. Thus, such heterogeneity in the aggregate return and social profitability of human capital should be considered when supporting and financing human capital as a tool for development policy. 
The conclusion from a social perspective is undoubtedly the confirmation that educational policy can really play a key role in regional economic development. Used correctly and in combination with other incentives, it should allow greater levels of productivity and income, together with a greater development of the least favored economies. If so, investments in human capital made in such regions would positively contribute to the process of regional convergence.

Whatever the case, there are a number of aspects arising from this study which need to be analyzed in greater detail in future studies. First, one could obtain measures of the profitability of investment at different levels of education, following for instance the suggestion in Di Liberto (2008) and Pereira and Aubyn (2009). Here, we have considered the shadow price as being homogenous for all levels of education; however, it would be interesting to check whether the effects may differ significantly from one level to another. On the other hand, as we have not included the opportunity cost of school attendance (foregone wages), our measure of the cost of education might be underestimating the real price of human capital investments. It might be of interest to include this opportunity cost as well as to consider some other elements linked to the level of education that have not been taken into account in the present analysis such as the change in the probability of being employed and the increase in taxes associated to higher wages. Undoubtedly, they might have a role when measuring the aggregate profitability of human capital investments.

Acknowledgements: The authors acknowledge financial support from Ministerio de Educación y Ciencia, Programa Nacional de I+D+I, ECO2008-05314 as well as from the project "Intangible Assets and Regional Economic Growth (IAREG)" financed by the European Union under the $7^{\text {th }}$ Framework Programme (FP7-SSH-2007-1. 216813). 


\section{REFERENCES}

ACEMOGLU, D and ANGRIST J (2001) How large are human capital externalities? Evidence from compulsory schooling laws?, NBER Macroeconomics Annual 2000, 9-59

AGHION P. and HOWITT P. (1998) Endogenous growth theory, The MIT Press, Cambridge, MA

ARRAZOLA M. and de HEVIA J. (2008) Three measures of returns to education: An illustration for the case of Spain, Economics of Education Review 27, 266-75

BARRO, R (2001) Human capital and growth, American Economic Review 91, 12-17

BARRO R and LEE J.W. (1993) International comparisons of educational attainment, Journal of Monetary Economics 32, 363-394

BARRO R and LEE J.W. (1996) International measures of schooling years and schooling quality, American Economic Review 86, 218-223

BARRO R and LEE J.W. (2001) International data on educational attainment: updates and implications, Oxford Economic Papers 53, 541-563

BASSANINI A and SCARPETTA S (2002) Does human capital matter for growth in OECD countries? A pooled mean-group approach, Economics Letters 74, 399-405

BENHABIB J and SPIEGEL M.M. (1994) The role of human capital in economic development: evidence from aggregate cross-country data, Journal of Monetary Economics 34, 143-173

BERNDT E.R. (1991) Modelling the interrelated demands for factors of production: estimation and inference in equation systems, in The Practice of Econometrics: Classic and Contemporary, Addison-Wesley, New York

BILS M and KLENOW P (2000) Does schooling cause growth? American Economic Review 90, $1160-1183$

BOSCÁ, J., ESCRIBÁ, F.J. and MURGUI, M.J (2002) The Effect of Public Infrastructure on the Private Productive Sector of Spanish Regions, Journal of Regional Science 42, 301-26

BROWN R.S. and CHRISTENSEN L.R. (1981) Estimating elasticities of substitution in a model of partial static equilibrium: an application to US agriculture, 1947 to 1974, in BERNDT E.R. and FIELDS B.C. (Eds) Modelling and measuring natural resource substitution, MIT Press, Cambridge MA 
CHAMBERS R (1988) Applied production analysis, Cambridge University Press, Cambridge

CICCONE A and PERI G (2006) Identifying Human Capital Externalities: Theory with Applications, Review of Economic Studies 73, 381-412

DABÁN T, DÍAZ A, ESCRIBÁ F.J. and MURGUI M.J. (1998) La base de datos BD.MORES, Dirección General de Análisis y Programación Presupuestaria, Ministerio de Economía y Hacienda. Doc Trab D-98001

DE LA FUENTE A and DOMÉNECH R (2006) Human capital in growth regressions: how much difference does data quality make?, Journal of the European Economic Association 4, 1-36

DÍAZ A (1998) Series de consumos intermedios por ramas de actividad y regiones españolas, 19801995, Dirección General de Análisis y Programación Presupuestaria, Ministerio de Economía y Hacienda

DI LIBERTO A (2008) Education and Italian regional development, Economics of Education Review $27,94-107$

ENGELBRECHT H (2003) Human capital and economic growth: cross-section evidence for OECD countries, Economic Record 79, 40-51

FINGLETON B. (2004) Some alternative geo-economics for Europe's regions," Journal of Economic Geography, 4, 389-420.

HEUERMANN D, HALFDANARSON B. and SUEDEKUM J (2010) Human capital externalities and the urban wage premium: Two literatures and their interrelations, Urban Studies 47, 749-767

KRUEGER A.B. and LINDAHL M (2001) Education and growth: why and for whom?, Journal of Economic Literature 39,1101-1136

KYRIACOU G (1991) Level and growth effects of human capital, Working paper C. Starr Center, New York University

LÓPEZ-BAZO E, REQUENA F and SERRANO G (2006) Complementarity between local knowledge and internationalization in regional technological progress, Journal of Regional Science 46, 901-929.

LUCAS R (1988) On the mechanics of economic development, Journal of Monetary Economics 22, 3- 
MANKIW N.G, ROMER D and WEIL D.N. (1992) A contribution to the empirics of economic growth, Quarterly Journal of Economics 107, 407-437

MAS M, PÉREZ F, URIEL E, SERRANO L and SOLER A (2002) Capital humano y actividad económica, series 1964-2001, Fundación Bancaixa, Valencia

MILLER, S and UPADHYAY M (2000) The Effects of Openness, Trade Orientation and Human Capital on Total Factor Productivity, Journal of Development Economics 63, 399-423

MORENO R, LÓPEZ-BAZO E and ARTÍS M (2002) Public infrastructure and the performance of manufacturing industries: short- and lon-run effects, Regional Science and Urban Economics 32, $97-121$

MORENO R, LÓPEZ-BAZO E and ARTÍS M (2003) On the effectiveness of Private and Public Capital, Applied Economics 35, 727-740

MORRISON, C.J. and SCHWARTZ, A.E. (1996) State infrastructure and productive performance, American Economic Review 86, 1095-1111

MORRISON C and SIEGEL D (1997) External capital factors and increasing returns in U.S. manufacturing, The Review of Economics and Statistics 79, 647-655

NADIRI I and MAMUNEAS T (1994) The effects of public infrastructure and R\&D capital on the cost structure and performance of U.S. manufacturing industries, The Review of Economics and Statistics 76, 189-198

PEREIRA J and AUBYN M (2009) What level of education matters most for growth?: Evidence from Portugal, Economics of Education Review 28, 67-73

RAUCH J (1993) Productivity gains from geographic concentration of human capital: evidence from the cities, Journal of Urban Economics 34, 380-400

RODRÍGUEZ-POSE, A. and VILALTA-BUFÍ, M. (2005) Education, migration, and job satisfaction: the regional returns of human capital in the EU, Journal of Economic Geography, 5, 545-566

ROMER P (1990) Endogenous technological change, Journal of Political Economy 98, S71-S102

SCHANKERMAN, M. and NADIRI M.I. (1986) A test of static equilibrium models and rates of return to quasi-fixed factors, with an application to the bell system, Journal of Econometrics 33, $97-118$ 
SERRANO L (1996) Indicadores de capital humano y productividad, Revista de Economía Aplicada IV(10), 177-190

TEMPLE J (1999) The new growth evidence, Journal of Economic Literature 37, 112-156

TEMPLE J (2001) Generalizations that aren't? Evidence on education and growth, European Economic Review 45, 905-918

TOPEL R (1999) Labour Market and economic growth, in ASHENFELTER, O. and CARD, D (Eds), The Handbook of Labour Economics, North-Holland, Amsterdam

URIEL E, MOLTÓ M.L., PÉREZ F, ALDÁS J and CUCARELLA V (1997) Las cuentas de la educación en España y sus comunidades autónomas: 1980-1992, Colección Economía Española vol. 4, Fundación Argentaria, Madrid.

WILLIS R.J. (1986) Wage determinants: A survey and reinterpretation of human capital earning functions, in ASHENFELTER O and LAYARD R (Eds) Handbook of Labour Economics vol I, North-Holland 
Figure 1. Educational attainment of the Spanish labour force

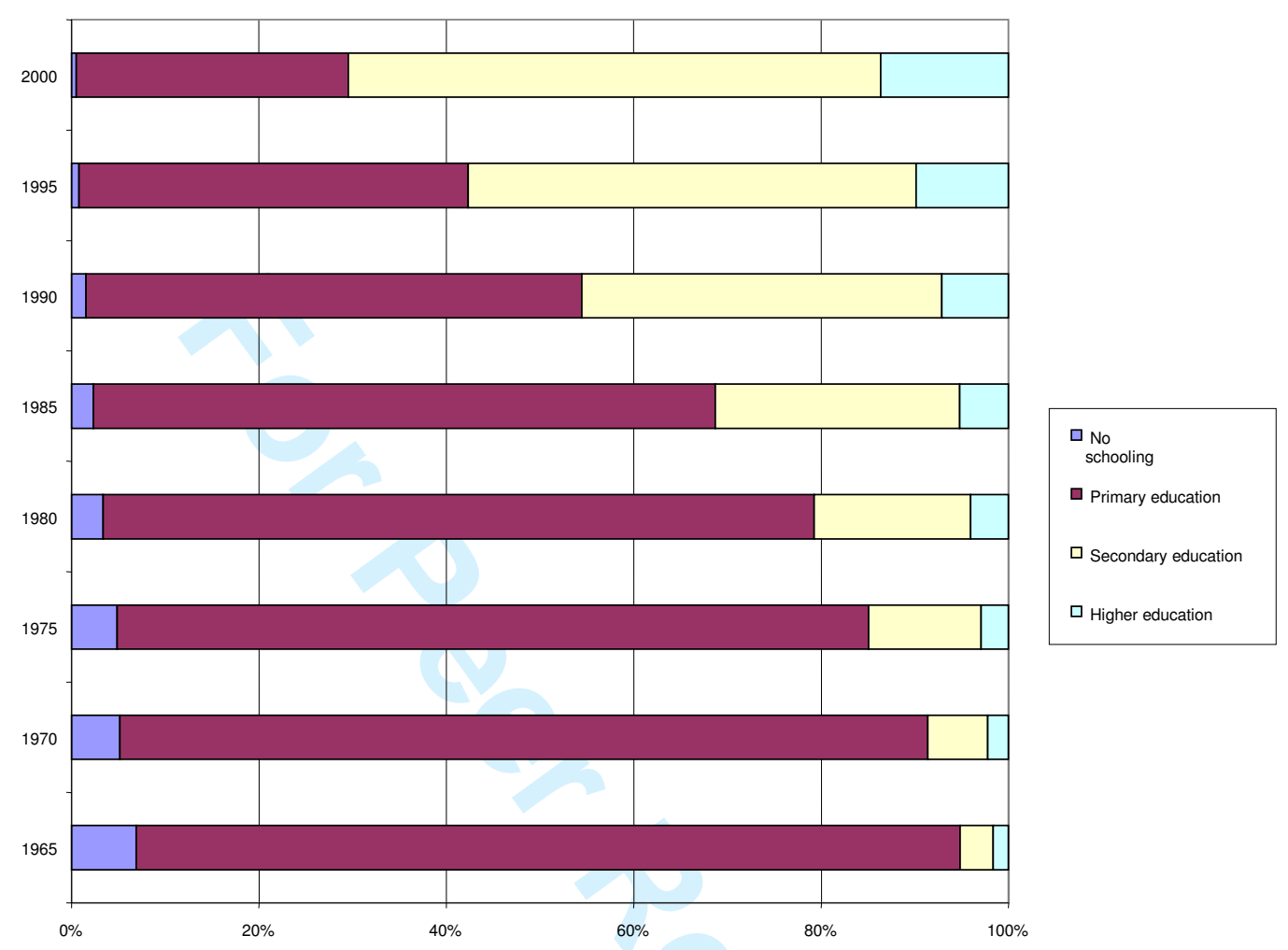


Figure 2. Evolution of the average years of education of employment in Spain

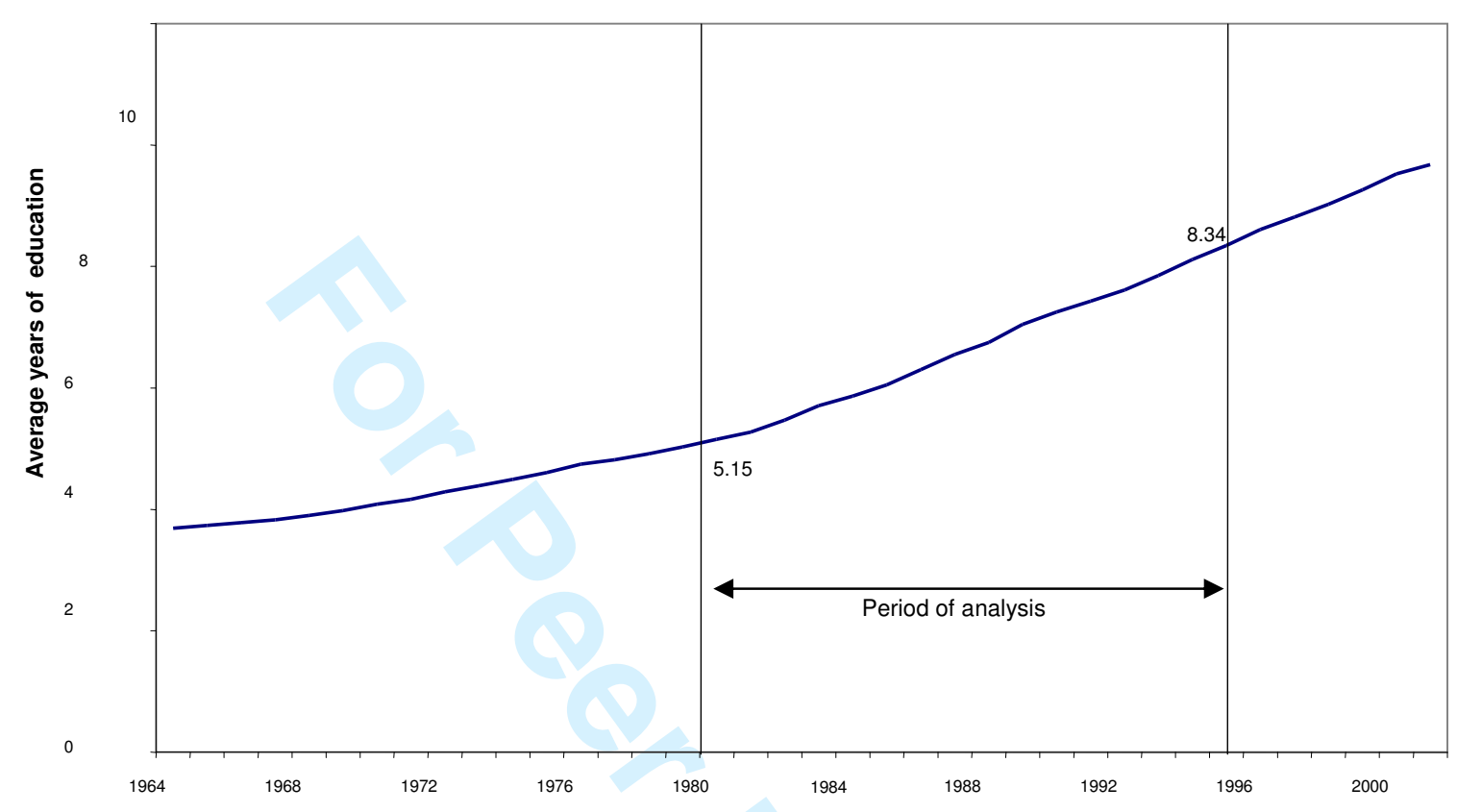


Figure 3. Average years of education in the Spanish regions

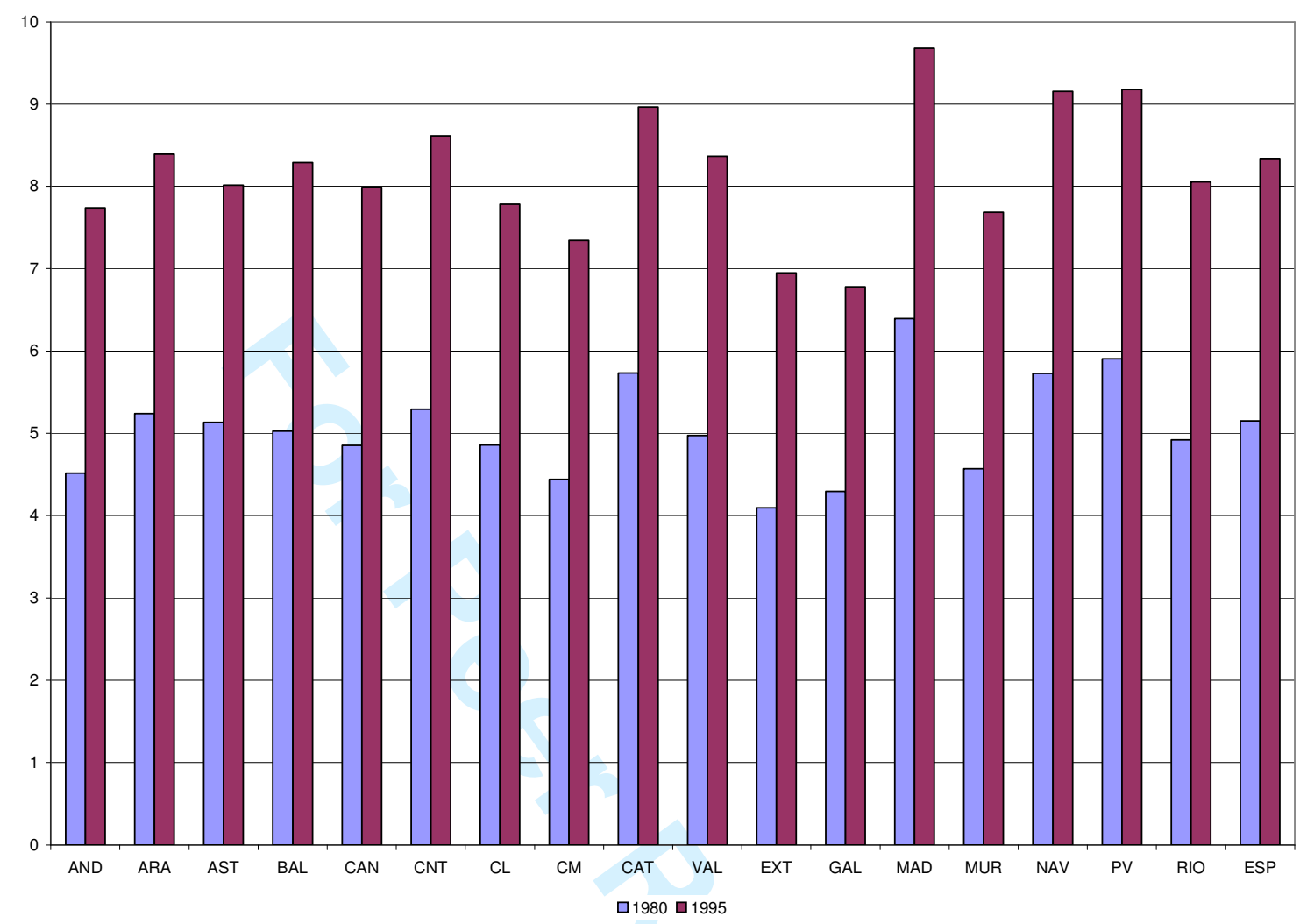

Note: Andalucia (AND), Aragon (ARA), Asturias (AST), Baleares (BAL), Canarias (CAN), Cantabria (CNT), Castilla-Leon (CL), Castilla-La Mancha (CM), Catalunya (CAT), Valencia (VAL), Extremadura (EXT), Galicia (GAL), Madrid (MAD), Murcia (MUR), Navarra (NAV), País Vasco (PV), Rioja (RIO), España (ESP) 
Figure 4. Returns to education with respect to the level of productivity (Y/L)

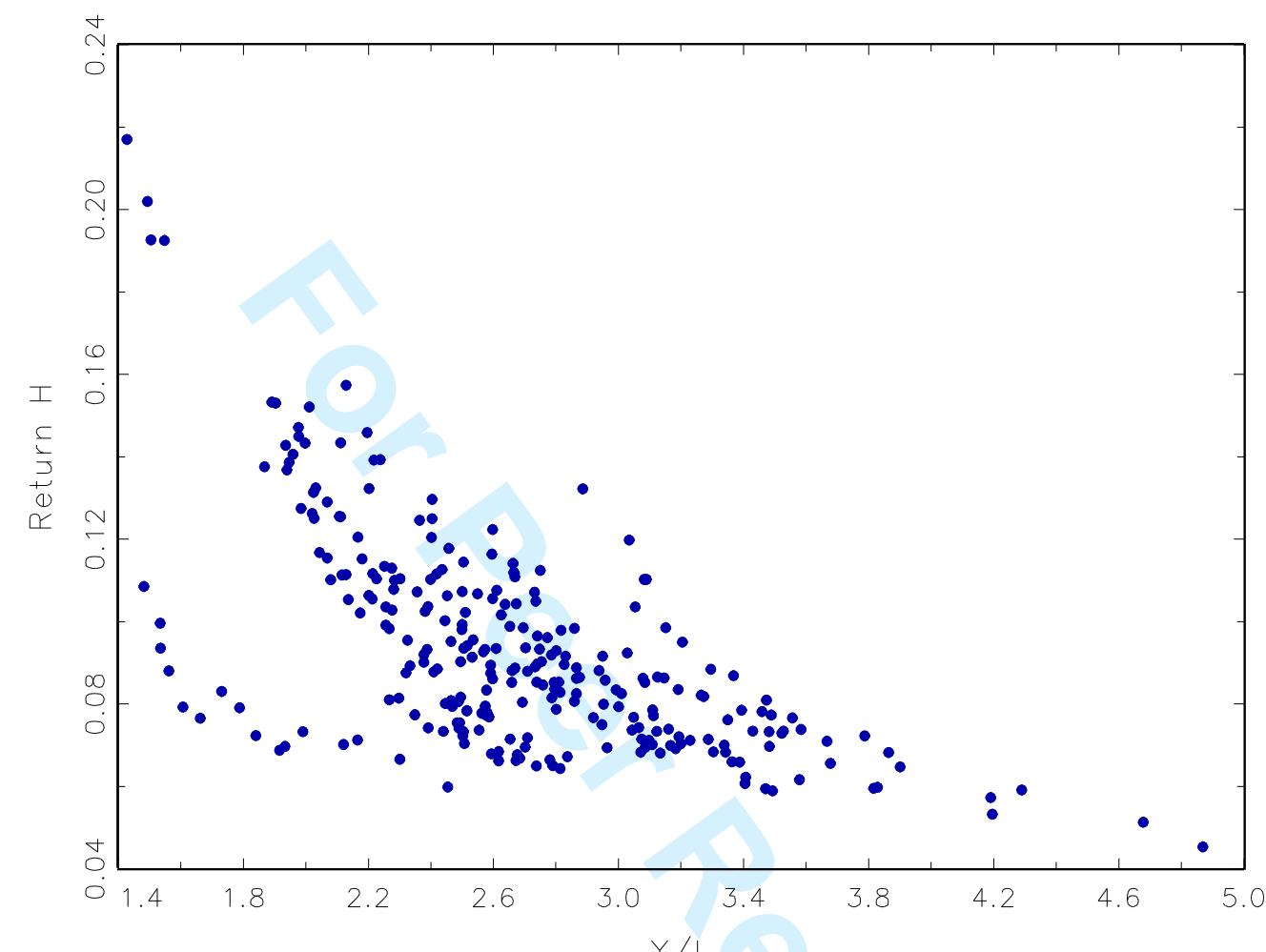

33 
Figure 5. Returns to education with respect to human-physical capital ratio (H/K)

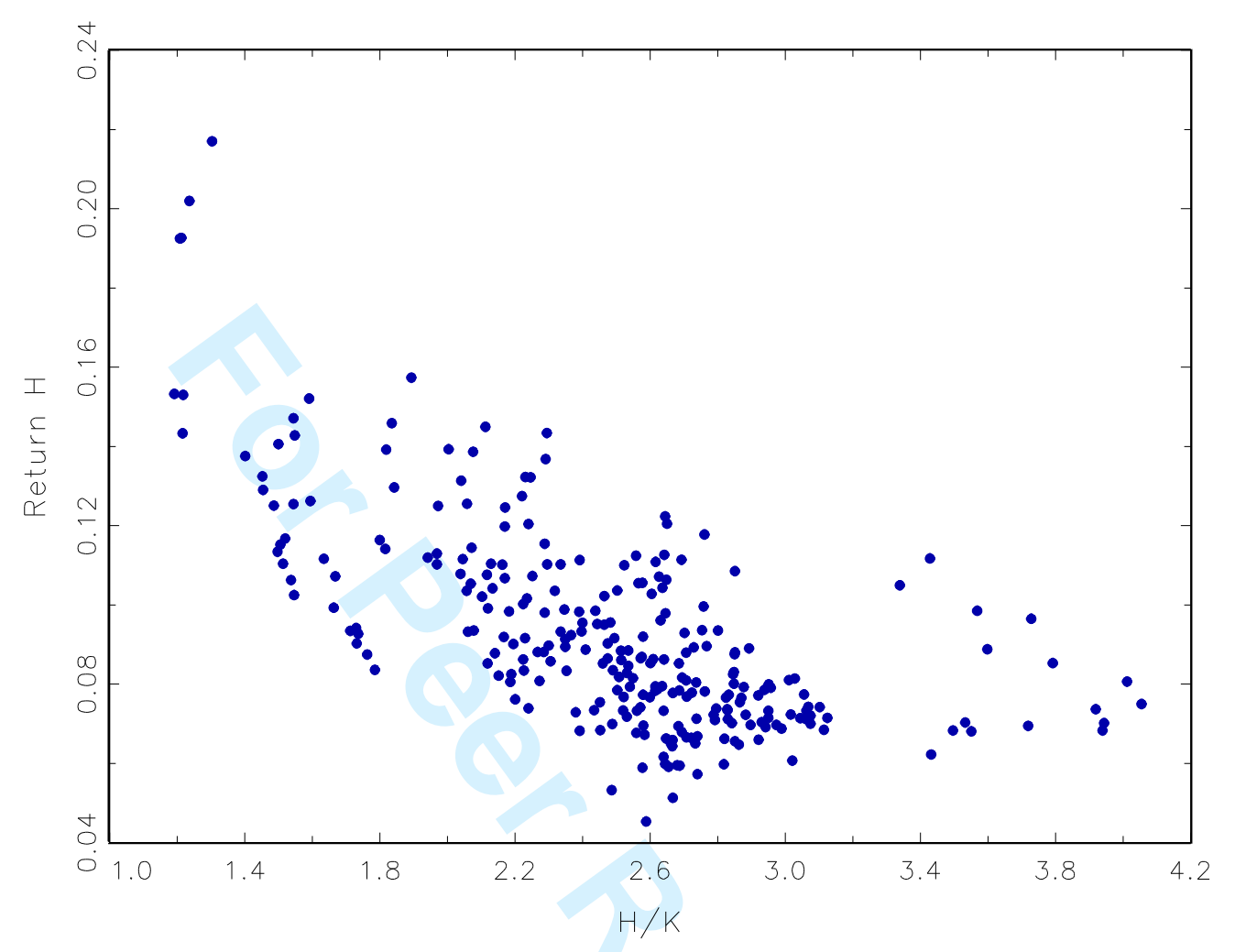


Table 1. Estimates of the partial static equilibrium model

\begin{tabular}{|c|c|c|c|c|}
\hline \multirow[b]{3}{*}{ Coefficient } & \multicolumn{2}{|c|}{ (i) } & \multicolumn{2}{|c|}{ (ii) } \\
\hline & \multicolumn{2}{|c|}{ Dependent var. : $\ln \left(\mathrm{VC} / \mathrm{P}_{\mathrm{M}}\right), \mathrm{S}_{\mathrm{L}}, \mathrm{S}_{\mathrm{Y}}$} & \multicolumn{2}{|c|}{ Dependent var.: $-S_{K}$} \\
\hline & Estimate & t-Ratio & Estimate & t-Ratio \\
\hline$\overline{\beta_{0}}$ & -3.484 & -5.231 & 0.160 & 1.976 \\
\hline$\beta_{\mathrm{L}}$ & 0.338 & 3.688 & & \\
\hline$\beta_{\mathrm{Y}}$ & -0.483 & -4.093 & & \\
\hline$\beta_{\mathrm{K}}$ & 1.866 & 13.954 & & \\
\hline$\beta_{\mathrm{H}}$ & 1.830 & 3.836 & & \\
\hline$\beta_{\mathrm{T}}$ & -0.089 & -5.242 & & \\
\hline$\beta_{\mathrm{LL}}$ & 0.132 & 11.259 & & \\
\hline$\beta_{\mathrm{YY}}$ & 0.012 & 1.848 & & \\
\hline$\beta_{\mathrm{KK}}$ & -0.041 & -4.482 & -0.062 & -11.573 \\
\hline$\beta_{\mathrm{HH}}$ & -0.900 & -6.869 & & \\
\hline$\beta_{\mathrm{TT}}$ & -0.001 & -3.324 & & \\
\hline$\beta_{\mathrm{LY}}$ & -0.152 & -12.269 & & \\
\hline$\beta_{\mathrm{LK}}$ & 0.171 & 15.484 & 0.011 & 0.546 \\
\hline$\beta_{\mathrm{LH}}$ & -0.067 & -2.487 & & \\
\hline$\beta_{\mathrm{LT}}$ & -0.005 & -4.101 & & \\
\hline$\beta_{\mathrm{YK}}$ & 0.012 & 0.951 & 0.120 & 9.369 \\
\hline$\beta_{\mathrm{YH}}$ & 0.659 & 19.873 & & \\
\hline$\beta_{\mathrm{YT}}$ & -0.015 & -12.036 & & \\
\hline$\beta_{\mathrm{KH}}$ & -0.639 & -14.075 & -0.120 & -4.776 \\
\hline$\beta_{\mathrm{KT}}$ & 0.015 & 9.421 & -0.002 & -1.815 \\
\hline$\beta_{\mathrm{HT}}$ & 0.060 & 6.829 & & \\
\hline $\mathrm{D}_{1} \beta_{\mathrm{L}}$ & 0.007 & 0.718 & & \\
\hline$D_{1} \beta_{Y}$ & -0.064 & -5.590 & & \\
\hline$D_{1} \beta_{K}$ & 0.066 & 5.537 & & \\
\hline $\mathrm{D}_{2} \beta_{\mathrm{L}}$ & 0.008 & 0.857 & & \\
\hline $\mathrm{D}_{2} \beta_{\mathrm{Y}}$ & 0.040 & 3.317 & & \\
\hline $\mathrm{D}_{2} \beta_{\mathrm{K}}$ & -0.042 & -3.311 & & \\
\hline $\mathrm{D}_{1}$ & & & 0.0112 & 1.247 \\
\hline $\mathrm{D}_{2}$ & & & -0.003 & -0.374 \\
\hline
\end{tabular}

$\mathrm{R}^{2}$ of Cost function (Eq 3)

0.997

$\mathrm{R}^{2}$ of Labor share (Eq 4)

0.676

$\mathrm{R}^{2}$ of Price $=$ Marginal Cost Equation $(\mathrm{Eq} 5)$

0.755

$\mathrm{R}^{2}$ of Physical Capital share

0.580

\# observations $(\mathrm{N}=17 ; \mathrm{T}=16)$

272

\# iterations

11

LR Test of SURE $-\chi^{2}(6)-$

108.8

p-val: 0.000

Wald Test:

Significance of regional dummies $-\chi^{2}(8)-$

Significance of human capital $-\chi^{2}(7)-$

40.8

818.1

p-val: 0.000

p-val: 0.000

\begin{abstract}
Note: SURE estimation of equations 34,5 and the equation for the physical capital share as described in the main text of section 4 . The restrictions between the parameters of equation 3 and those of equations 4 and 5 are imposed (column i), whereas the equation of the share of physical capital is estimated in the SURE model without imposing restrictions with parameters of the other equations, in accordance with the framework of the partial static equilibrium (column ii).
\end{abstract}


Table 2. Regional and time effects of education

\begin{tabular}{lcc|ccc}
\hline \hline & $\begin{array}{c}\text { Cost elasticity of } \\
\text { education } \\
\left(\varepsilon_{\mathrm{SC}, \mathrm{H}}\right)\end{array}$ & $\begin{array}{c}\text { Return to } \\
\text { education } \\
\left(\mathrm{R}_{\mathrm{H}}\right)\end{array}$ & & $\begin{array}{c}\text { Cost elasticity of } \\
\text { education } \\
\left(\varepsilon_{\mathrm{SC}, \mathrm{H}}\right)\end{array}$ & $\begin{array}{c}\text { Return to } \\
\text { education } \\
\left(\mathrm{R}_{\mathrm{H}}\right)\end{array}$ \\
\hline & & & & & \\
ANDALUCIA & -0.496 & 0.081 & 1980 & -0.708 & 0.131 \\
ARAGON & -0.791 & 0.106 & 1981 & -0.676 & 0.121 \\
ASTURIAS & -0.637 & 0.091 & 1982 & -0.672 & 0.115 \\
BALEARES & -0.678 & 0.092 & 1983 & -0.686 & 0.112 \\
CANARIAS & -0.620 & 0.092 & 1984 & -0.638 & 0.100 \\
CANTABRIA & -0.767 & 0.100 & 1985 & -0.628 & 0.095 \\
CAST -LEON & -0.668 & 0.104 & 1986 & -0.649 & 0.096 \\
CAST- LA MANCHA & -0.668 & 0.114 & 1987 & -0.629 & 0.089 \\
CATALUNYA & -0.729 & 0.085 & 1988 & -0.632 & 0.086 \\
VALENCIA & -0.599 & 0.085 & 1989 & -0.632 & 0.082 \\
EXTREMADURA & -0.726 & 0.144 & 1990 & -0.630 & 0.079 \\
GALICIA & -0.404 & 0.078 & 1991 & -0.640 & 0.078 \\
MADRID & -0.800 & 0.080 & 1992 & -0.633 & 0.076 \\
MURCIA & -0.508 & 0.081 & 1993 & -0.671 & 0.078 \\
NAVARRA & -0.748 & 0.086 & 1994 & -0.664 & 0.074 \\
PAIS VASCO & -0.795 & 0.091 & 1995 & -0.632 & 0.069 \\
RIOJA & -0.439 & 0.062 & & & \\
& & & & & \\
Average for Spain & -0.652 & 0.093 & & & \\
\hline \hline
\end{tabular}


Table 3. Shadow price of education and its cost of provision

ANDALUCIA

ARAGON

ASTURIAS

4.042

3.324

BALEARES

3.329

CANTABRIA

2.883

CAST -LEON

3.520

3.580

CATALUNYA

3.329

2.712

4.001

2.075

3.143

2.575

3.582

3.876

3.059

PAIS VASCO

RIOJA

3.558

3.034

4.037

1.971

2.923

2.944

3.464

3.630

2.941

Note: Shadow price per worker $\left(\mathrm{Z}_{\mathrm{H}} / \mathrm{L}\right)$ is given in thousands of euros. Relative $\mathrm{P}_{\mathrm{H}}$ is the cost of education in each region relative to the Spanish average cost. $\mathrm{q}_{\mathrm{H}}-$ Ratio is a Tobin type measure obtained as the ratio of the shadow price of education and the cost of an additional year of education. 


\footnotetext{
${ }^{1}$ Throughout the paper we use indiscriminately the terms human capital and education since we are referring specifically to the human capital acquired in the formal educational system.

${ }^{2}$ The use of the dual approach has been much more frequent in analyzing the effects of investments in infrastructure and public capital (e.g. Nadiri and Mamuneas, 1994; Morrison and Schwartz, 1996; Moreno, López-Bazo \& Artís, 2002).

${ }^{3}$ The macroeconomic evidence on the impact of educational human capital presented to-date has been based on the analysis of the aggregate return to human capital obtained through the application of a range of specifications centered on a primal approach - in other words, basing the analysis within a production function framework (see the survey in Krueger and Lindahl, 2001). As said above, an alternative and complementary approach to analyze the effect of human capital at the aggregate level —and one that is virtually unexploredis the one based on the duality theory.

${ }^{4}$ This corresponds to a partial static equilibrium model where physical capital cannot be instantaneously adjusted to the optimum stock in every time period. A full static equilibrium can also be defined in which that type of capital is assumed to be always in equilibrium (see for instance Brown and Christensen, 1981 for further details). Our preference for the partial static equilibrium model lies in the result of the formal test proposed by Schankerman and Nadiri (1986) to the data used in the empirical section of this paper. Detailed results are available upon request.

${ }^{5}$ NUTS is the French acronym for Nomenclature of Territorial Units for Statistics, a hierarchical classification established by EUROSTAT to provide comparable regional breakdowns of EU Member States. In the case of Spain, the NUTS II regions correspond to the 17 Autonomous Communities, historical and administrative regions with a high level of political and financial autonomy.

${ }^{6}$ Alternatives, such as the rate of schooling or the literacy rate have been subjected to considerable criticism due to their clear limitations when approximating an economy's human capital stock. They have, however, been used in several studies because of the impossibility of obtaining detailed information about the levels of education of the population.

${ }^{7}$ Comparable regional dummies were considered when estimating an aggregate cost system for the Spanish regions in Boscá, Escribá \& Murgui (2002).

${ }^{8}$ We follow Morrison and Schwartz (1996) in taking this decision.
} 
${ }^{9}$ To identify the impact of the aggregate stock of education in the economy, we follow the idea in Morrison and Siegel (1997) that human capital, as an external factor, can cause downward shifts of cost curves, so that their effect on aggregate productivity can be examined through a cost-function approach. It should then be noted that our approach differs from the one based on estimating human capital externalities from a Mincerian approach (see among others Rauch, 1993; Acemoglu and Angrist, 2001; Ciccone and Peri, 2006; and Heuermann et al, 2010 for a recent survey). The use of a cost function to analyse the effect of human capital must be understood therefore as parallel to the common practice in economic growth literature of using a production function aggregated with the stock of human capital (see for instance Topel, 1999). Both frameworks lie on the same idea that a higher endowment of human capital in the economy may imply higher productivity growth. In the duality framework, this result implies that additional investment in human capital results in a downward shift in the aggregate cost function.

${ }^{10}$ The set of effects for each of the regions in each of the years is available upon request.

${ }^{11}$ By way of example, estimations of the return on investments in public productive capital on the Spanish economy in a similar period stand at around 3\% (e.g. 2.8\% in Moreno, López-Bazo \& Artís, 2003, and 2.6\% in Boscá et al, 2002).

${ }^{12}$ A similar trend is observed when the yearly average for each region is plotted against its average level of productivity over the period.

${ }^{13}$ The same temporal profile was recorded in each of the Spanish regions. Results are available upon request. 